\title{
Correction to: Genome wide meta-analysis of cDNA datasets reveals new target gene signatures of colorectal cancer based on systems biology approach
}

Umair llyas ${ }^{1 *}$, Shahiq uz Zaman ${ }^{1}$, Reem Altaf ${ }^{2}$, Humaira Nadeem² and Syed Aun Muhammad ${ }^{3}$

\section{Correction to: J Biol Res-Thessaloniki (2020) 27:8}

https://doi.org/10.1186/s40709-020-00118-1

Following publication of the original article [1], the authors identified an error in the author name of Shahiq uz Zaman.

The incorrect author name is: Shaiq uz Zaman.

The correct author name is: Shahiq uz Zaman.

The author group has been updated above and the original article [1] has been corrected.

\section{Author details}

${ }^{1}$ Department of Pharmaceutics, Faculty of Pharmaceutical Sciences, Riphah International University, Islamabad 44000, Pakistan. ${ }^{2}$ Department of Pharmaceutical Chemistry, Faculty of Pharmaceutical Sciences, Riphah International University, Islamabad 44000, Pakistan. ${ }^{3}$ Institute of Molecular Biology and Biotechnology, Bahauddin Zakariya University, Multan 66000, Pakistan.

Published online: 06 July 2020

\section{Reference}

1. Ilyas U, Zaman SU, Altaf R, et al. Genome wide meta-analysis of cDNA datasets reveals new target gene signatures of colorectal cancer based on systems biology approach. J of Biol Res-Thessaloniki. 2020;27:8. https ://doi.org/10.1186/s40709-020-00118-1.

The original article can be found online at https://doi.org/10.1186/s4070 9-020-00118-1.

*Correspondence: umair.ilyas@riphah.edu.pk

1 Department of Pharmaceutics, Faculty of Pharmaceutical Sciences, Riphah International University, Islamabad 44000, Pakistan

Full list of author information is available at the end of the article

\section{Publisher's Note}

Springer Nature remains neutral with regard to jurisdictional claims in published maps and institutional affiliations.

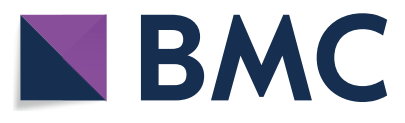

(0 The Author(s) 2020. This article is licensed under a Creative Commons Attribution 4.0 International License, which permits use, sharing, adaptation, distribution and reproduction in any medium or format, as long as you give appropriate credit to the original author(s) and the source, provide a link to the Creative Commons licence, and indicate if changes were made. The images or other third party material in this article are included in the article's Creative Commons licence, unless indicated otherwise in a credit line to the material. If material is not included in the article's Creative Commons licence and your intended use is not permitted by statutory regulation or exceeds the permitted use, you will need to obtain permission directly from the copyright holder. To view a copy of this licence, visit http://creativecommons.org/licenses/by/4.0/. The Creative Commons Public Domain Dedication waiver (http//creativecommons.org/publicdomain/Zero/1.0/) applies to the data made available in this article, unless otherwise stated in a credit line to the data. 